\title{
Review
}

\section{Docetaxel induction therapy in locally advanced squamous cell carcinoma of the head and neck}

\author{
MR Posner*,' and JL Lefebvre ${ }^{2}$ \\ 'Head and Neck Oncology Program, Dana-Farber Cancer Institute, SW430H, 44 Binney street, Boston, MA 02II 5, USA; ${ }^{2}$ Oscar Lambret Center, \\ 3 rue Combemale, 59020 Lille, France
}

\begin{abstract}
Patients with locally advanced squamous cell carcinoma of the head and neck (SCCHN) are often treated with induction chemotherapy or chemoradiotherapy, but to date without major impact on survival. The combination of cisplatin-5-fluorouracil (5-FU) (PF) has been used as standard induction therapy; however, poor patient survival has stimulated investigation into new agents with potential activity in SCCHN. Docetaxel has significant single-agent activity in SCCHN and has been investigated in combination with PF regimens as induction therapy. The results of six phase II studies of docetaxel-PF regimens (TPF) as induction in locally advanced SCCHN patients are reviewed and reported. Consistently, high 2-year survival rates and overall response rates were demonstrated across the phase II trials in the range $42-82$ and $71-100 \%$, respectively. The toxicity profile seen with TPF-based regimens was acceptable. The primary toxicity was neutropenia, which together with gastrointestinal complaints accounted for the majority of adverse events. Given the encouraging phase II experience with TPF-based regimens, two large-scale phase III studies comparing TPF-based regimens with standard PF regimens are underway. The results have significant potential for validating the findings of the phase II studies, demonstrating improved survival and overall response of patients treated with docetaxel-based induction chemotherapy.
\end{abstract}

British Journal of Cancer (2003) 88, II - I7. doi: I0.1038/sj.bjc.6600685 www.bjcancer.com

(c) 2003 Cancer Research UK

Keywords: docetaxel; induction; PF regimens; squamous cell carcinoma of the head and neck

Squamous cell cancer of the head and neck (SCCHN) is a significant international problem. Cancer specific to the mouth and pharynx is the sixth most common cancer worldwide, and the third most common cancer among men in developing countries (Johnson, 2001). Men are at higher risk of developing these cancers and are affected 2-3 times as often as women in industrialised countries. There are approximately 400000 new cases of SCCHN projected annually (Parkin and Muir, 1992). Most SCCHN cases are locally advanced at presentation, with up to $75 \%$ of patients having stage III - IV, M0 disease (Dreyfuss et al, 1996; Parker, 1996). Stage of disease at diagnosis is regarded as the single most important prognostic factor (Forastiere, 2000). Stage I - II SCCHN is often curable with either surgery or radiotherapy, but it is generally accepted that treatment of locally advanced SCCHN should involve a combined modality approach (Forastiere, 2000).

Surgery and/or radiotherapy remain cornerstones of therapy in patients with locally advanced SCCHN. However, induction chemotherapy and chemoradiotherapy are now firmly integrated in locoregional care. Controlled studies have established cisplatin and continuous-infusion 5-fluorouracil (5-FU) as the standard induction regimen for unresectable locally advanced SCCHN patients (Paccagnella et al, 1994; Lefebvre et al, 1996; Domenge

\footnotetext{
*Correspondence: Dr MR Posner;

E-mail: marshall_posner@dfci.harvard.edu

Received 24 April 2002; revised 26 September 2002; accepted I October 2002
}

et al, 2000; Pignon et al, 2000). Up to $40 \%$ of chemonaïve locally advanced SCCHN patients treated with cisplatin-5-FU (PF) have been reported to achieve a complete response, with an overall response rate (ORR) in the range of $85 \%$ (Schantz et al, 2001). The main toxicities associated with PF-induction therapy are haematological, digestive and mucositis with the majority of events being grade I or II (Paccagnella et al, 1994; Domenge et al, 2000). Despite inducing locoregional control, high response rates and a significant improvement in survival, PF induction therapy is associated with a relatively poor absolute rate of patient survival, which is similar to that seen with intensive chemoradiotherapy regimens (Paccagnella et al, 1994; Lefebvre et al, 1996; Domenge et al, 2000; Pignon et al, 2000). The dose-intensive cisplatin-5$\mathrm{FU}$ - leucovorin (PFL) combination was subsequently developed in an attempt to improve complete response rates to induction chemotherapy and thus survival. The addition of leucovorin resulted in higher complete response rates at the expense of increased toxicity (Vokes et al, 1990; Schneider et al, 1995; Clark et al, 1997).

The need for further improvements in SCCHN care has stimulated intensive investigation into new agents with potential in induction chemotherapy and chemoradiotherapy regimens. New agents such as epidermal growth factor receptor (EGFR) inhibitor ZD1839 (Iressa $^{\mathrm{TM}}$ ), antibody C225 (Cetuximab ${ }^{\mathrm{TM}}$ ) and inhibitor OSI-774 (Tarceva ${ }^{\mathrm{TM}}$ ), in addition to farnesyl transferase inhibitors, have shown some promise in early studies. Although they are relatively ineffective as single agents, their combination with other agents (radiation and/or cytotoxic drugs) is under 
evaluation and may be of interest. UFT (a mixed compound of 5-FU and uracil) has shown promising single-agent activity, but combination therapy has yet to be studied. Alpha interferon has been tested as a potentiator of PFL or PF chemotherapy, but a phase III trial has failed to demonstrate any additional advantages from this approach (Vokes et al, 1995; Schrijvers et al, 1998). Perhaps the most promising agents have been the taxanes. In particular, the taxane docetaxel has demonstrated significant single-agent activity in recurrent SCCHN (Catimel et al, 1994; Dreyfuss et al, 1996; Couteau et al, 1999). Docetaxel is similar to paclitaxel with respect to its general mechanism of action (tubulin stabilization and cell cycle arrest), and the two share a number of pharmacological characteristics (Colevas and Posner, 2001). However, docetaxel and paclitaxel have somewhat different pharmacodynamics and toxicities that may be important in combination therapy programmes. Docetaxel, for example, has a greater affinity for tubulin, a longer intracellular half-life, and promotes microtubule stabilization at lower drug concentrations (Lavelle et al, 1995). The major toxicity associated with docetaxel is highly predictable myelotoxicity (Posner, 2001a). More importantly, neuropathy, a dominant side effect of cisplatin, is minimal with docetaxel-containing regimens, but can be significant in paclitaxel-containing regimens (Schrijvers and Vermorken, 2000; Colevas and Posner, 2001; Posner, 2001a). The differing mechanisms of action, and relative nonoverlapping toxicities compared with $\mathrm{PF}$, have prompted interest in the addition of docetaxel to PF regimens.

\section{POTENTIAL OF DOCETAXEL IN SCCHN}

In early preclinical studies, docetaxel demonstrated pronounced in vitro and in vivo cytotoxicity against a variety of human cancer cell lines, particularly head and neck cancer (Braakhuis et al, 1994). In fact, docetaxel was more effective than cisplatin in inhibiting the growth of two SCCHN xenograft models (HNX-14C and HNX-22B) (Braakhuis et al, 1994). Further preclinical evidence for docetaxel efficacy has been derived from studies employing a murine model, representative of human head and neck cancer (Sommer et al, 2001). From the drugs investigated (cisplatin, carboplatin, docetaxel, methotrexate, 5-FU), as single agents or in combination, an ifosfamide - docetaxel combination produced the best tumourfree survival.

The clinical efficacy and safety of docetaxel in SCCHN was initially established in patients with metastatic or recurrent/ incurable SCCHN. In three phase II studies (Table 1), single-agent docetaxel $\left(100 \mathrm{mg} \mathrm{m}^{-2}\right)$ administered on day 1 every 3 weeks produced response rates ranging from 21 to $42 \%$ (Catimel et al, 1994; Dreyfuss et al, 1996; Couteau et al, 1999). As expected, grade III - IV neutropenia was the principal toxicity in these studies. These results compare favourably with other single agents in the management of SCCHN (Schoffski et al, 1998; Posner, 2001a).

Table I Phase II studies with single-agent docetaxel in patients with $\mathrm{SCCHN}$

\begin{tabular}{|c|c|c|c|}
\hline $\begin{array}{l}\text { Study } \\
\text { reference }\end{array}$ & Dose/schedule & $\begin{array}{c}\mathbf{N} \text { (evaluable } \\
\text { patients) }\end{array}$ & $\begin{array}{c}\text { Response } \\
\text { rate (\%) }\end{array}$ \\
\hline Catimel et al (1994) & $\begin{array}{l}100 \mathrm{mg} \mathrm{m}^{-2} \\
\text { dl q3w }\end{array}$ & 37 & 32 \\
\hline Dreyfuss et al (1996) & $\begin{array}{l}100 \mathrm{mgm}^{-2} \\
\mathrm{dl} \mathrm{q3w}\end{array}$ & 29 & 42 \\
\hline Couteau et al (1999) & $\begin{array}{l}100 \mathrm{mg} \mathrm{m}^{-2} \\
\mathrm{dl} \mathrm{q3w}\end{array}$ & 21 & 21 \\
\hline
\end{tabular}

Phase I/II studies combining docetaxel with cisplatin and/or 5 -FU were undertaken in recurrent or metastatic SCCHN patients to look for improved efficacy and safety. In two trials, docetaxel 5 -FU resulted in ORRs of 24 and 27\% (Colevas et al, 2000; Tubiana-Mathieu et al, 2000). Docetaxel - cisplatin appeared to be a more effective combination, with overall response rates ranging from 33 to 76\% (Kienzer et al, 1998; Schoffski et al, 1999; Specht et al, 2000; Glisson et al, 2002). In the trial conducted by the European Organisation for the Research and Treatment of Cancer (EORTC), docetaxel $\left(100 \mathrm{mg} \mathrm{m}^{-2}\right)$ plus cisplatin $\left(75 \mathrm{mg} \mathrm{m}^{-2}\right)$ produced a response rate of $54 \%$ (Schoffski et al, 1999). Of the 44 patients enrolled in this trial, 22 were chemotherapy-naïve and the response rate in this group was $86 \%$. As with single-agent docetaxel, the main toxicity in each of the combination studies was myelosuppression (Kienzer et al, 1998; Schoffski et al, 1999; Colevas et al, 2000; Specht et al, 2000; Tubiana-Mathieu et al, 2000; Glisson et al, 2002). Mucositis was more commonly seen in the combination studies (particularly docetaxel-5-FU) than with single-agent docetaxel.

\section{DOCETAXEL INDUCTION THERAPY IN SCCHN: PHASE II RESULTS}

The promising response rates and tolerability profiles exhibited in recurrent or metastatic SCCHN patients treated with docetaxelcisplatin led to the investigation of docetaxel regimens as induction therapy for locally advanced disease. Two phase II induction studies with docetaxel $75 \mathrm{mg} \mathrm{m}^{-2}$ plus cisplatin 75 or $100 \mathrm{mg} \mathrm{m}^{-2}$ i.v. every 3 weeks followed by definitive radiotherapy in patients with locally advanced SCCHN have been reported (Mel et al, 2000; Caponigro et al, 2001). In an intention-to-treat analysis, objective responses of $62 \%$ and $46 \%$ were seen in patients during the induction phase, with corresponding complete response rates of $17 \%$ (Mel et al, 2000) and $11 \%$ (Caponigro et al, 2001), respectively. Grade III - IV neutropenia was experienced by $74 \%$ of patients in one study, although febrile neutropenia affected only $17 \%$ of patients (Mel et al, 2000). In the second study, $61 \%$ of patients experienced grade III-IV neutropenia, which was complicated by fatal sepsis in $2(4 \%)$ patients (Caponigro et al, 2001). The authors suggest that these toxic deaths might have been related to the higher dose of cisplatin $\left(100 \mathrm{mg} \mathrm{m}^{-2}\right)$ used in their study (Caponigro et al, 2001). The incidences of grade III-IV nonhaematological toxicity, including gastrointestinal complications, were relatively low in both studies. These results, in a heterogeneous group of patients with moderate-to-poor performance status, were similar to the data seen with PF. With data from recurrent patients, these studies demonstrate that the docetaxel-cisplatin combination has interactive efficacy similar to that seen with PF.

Rather than substituting cisplatin or 5-FU with a newer SCCHNactive agent such as docetaxel, in the curative setting, most research is now focused on the addition of docetaxel to PF-based regimens. Studies involving docetaxel-PF-based regimens demonstrate a high likelihood of superior clinical benefit $v s$ current treatment options in terms of response rate and survival.

\section{Docetaxel plus modified PFL regimens}

Three trials conducted at the Dana-Farber Cancer Institute administered docetaxel with PFL in SCCHN patients with advanced disease, who were potentially curable (Table 2) (Colevas et al, 1998; 1999; 2002). In the first study, TPFL-5, 23 patients with stage III - IV SCCHN received docetaxel $25-60 \mathrm{mg} \mathrm{m}^{-2} \mathrm{~d} 1$ (day 1), cisplatin $25 \mathrm{mg} \mathrm{m}^{-2} \mathrm{~d} 1-5, \quad 5$-FU $\quad 700 \mathrm{mg} \mathrm{m}^{-2} \quad(N=21)$ or $800 \mathrm{mg} \mathrm{m}^{-2}(N=2) \mathrm{d} 2-5$ and leucovorin $500 \mathrm{mg} \mathrm{m}^{-2} \mathrm{~d} 1-5$ every 4 weeks for three cycles (Colevas et al, 1998). The ORR prior to definitive, twice daily radiation therapy was $100 \%$, consisting of 14 
Table 2 Docetaxel plus modified PFL induction regimens for locally advanced SCCHN

\begin{tabular}{|c|c|c|c|c|c|c|}
\hline $\begin{array}{l}\text { Study } \\
\text { reference }\end{array}$ & $\begin{array}{l}\text { Number of } \\
\text { patients } \\
\text { entered }\end{array}$ & $\begin{array}{l}\text { Patient/disease } \\
\text { characteristics }\end{array}$ & Regimen & $\mathrm{OR}^{\mathrm{a}}(\%)$ & $\mathbf{C R}^{\mathrm{a}}(\%)$ & $\begin{array}{l}\text { Grade III-IV } \\
\text { toxicities } \\
\text { in } \geqslant 5 \% \text { of } \\
\text { patients or } \\
\text { cycles }(\%)\end{array}$ \\
\hline $\begin{array}{l}\text { Colevas et al } \\
\text { (1998) } \\
\text { Phase I/II } \\
(n=24)\end{array}$ & 23 & $\begin{array}{l}\text { Previously untreated stage III or } \\
\text { nonmetastatic stage IV SCCHN }\end{array}$ & $\begin{array}{l}\text { TPFL-5: docetaxel } 25-60 \mathrm{mg} \mathrm{m}^{-2} \text { i.v. dl; } \\
\text { cisplatin } 25 \mathrm{mg} \mathrm{m}^{-2} \text { day }^{-1} \mathrm{CIVI} \mathrm{dl}^{-5} 5-\mathrm{FU} \\
700 \text { or } 800 \mathrm{mg} \mathrm{m}^{-2} \text { day }^{-1} \mathrm{CIVI} \mathrm{d2}-5 ; \\
\text { leucovorin } 500 \mathrm{mg} \mathrm{m}^{-2} \text { day }^{-1} \mathrm{CIVI} \mathrm{dl}-5 \\
\text { Repeat q4wk for up to three cycles, } \\
\text { followed by definitive BID RT }\end{array}$ & 100 & 61 & $\begin{array}{l}\% \text { of cycles at the MTD of } \\
\text { docetaxel } 60 \mathrm{mg} \mathrm{m}^{-2} \text { i.v. }(n=45) \text { : } \\
\text { mucositis ( } 46) \text {; neutropenia } \\
\text { (22); febrile neutropenia ( } 22) \text {; } \\
\text { nausea (I I); diarrhoea ( I I); } \\
\text { infection (7); renal tubular (7) }\end{array}$ \\
\hline $\begin{array}{l}\text { Colevas et al } \\
(1999) \\
\text { Phase II } \\
(n=30)\end{array}$ & 30 & $\begin{array}{l}\text { Previously untreated stage III or } \\
\text { nonmetastatic stage IV SCCHN }\end{array}$ & 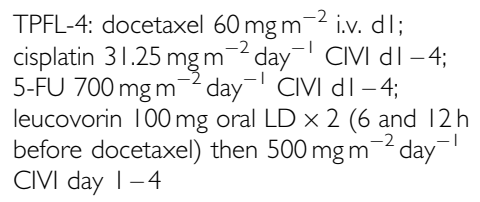 & , & 63 & $\begin{array}{l}\text { \% of TPFL-4 cycles: mucositis } \\
\text { (48); nausea/vomiting (I5); } \\
\text { neutropenia (8); thrombocytopenia } \\
\text { (6); anorexia (6); diarrhoea (5); } \\
\text { infection (5); renal toxicity (5) }\end{array}$ \\
\hline $\begin{array}{l}\text { Colevas et al } \\
(2002) \\
\text { Phase I/II } \\
(n=34)\end{array}$ & 34 & $\begin{array}{l}\text { Previously untreated stage III or } \\
\text { nonmetastatic stage IV SCCHN }\end{array}$ & 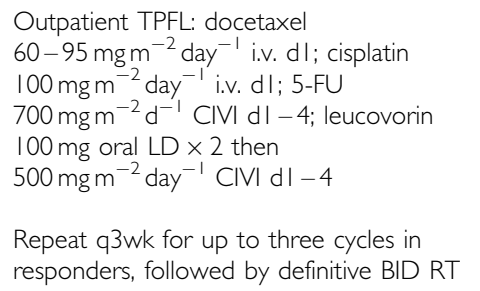 & 94 & 44 & $\begin{array}{l}\% \text { of patients at the MTD of } \\
\text { docetaxel } 90 \mathrm{mg} \mathrm{m}^{-2} \text { i.v. }(n=\mid 5) \text { : } \\
\text { neutropenia (67); mucositis (33); } \\
\text { nausea (I3); anorexia (I3); } \\
\text { fatigue (I3); febrile neutropenia (7); } \\
\text { thrombocytopenia (7); diarrhoea } \\
\text { (7); hepatotoxicity (7); } \\
\text { hyponatraemia (7); pain (7) }\end{array}$ \\
\hline
\end{tabular}

Abbreviations: $\mathrm{SCCHN=squamous} \mathrm{cell} \mathrm{carcinoma} \mathrm{of} \mathrm{the} \mathrm{head} \mathrm{and} \mathrm{neck;} \mathrm{OR=overall} \mathrm{response;} \mathrm{CR}=$ complete response; ECOG=Eastern Cooperative Oncology Group; $\mathrm{PS}=$ performance status; TPFL=docetaxel/cisplatin/5-fluorouraci/leucovorin; i.v.=intravenously; 5-FU=5-fluorouracil; CIVI=continuous intravenous infusion; LD=loading dose; $\mathrm{RT}=$ radiotherapy; MTD=maximum tolerated dose; BID=Twice Daily Hyperfractionated

${ }^{\mathrm{a}}$ For the evaluable population.

complete responses (CRs; 61\%) and nine partial responses (PRs; $39 \%$ ). Updated survival data (median follow-up 43 months) revealed both the 3-year overall survival and disease-free survival rates to be $78 \%$ (Posner et al, 2000). Approximately $40 \%$ of patients receiving the maximum tolerated dose (MTD) of docetaxel were hospitalised for neutropenia despite administration of granulocyte colony-stimulating factor (G-CSF) d5 - 10 and ciprofloxacin d5-15 (Colevas et al, 1998). Mucositis was the most prominent grade III-IV nonhaematological toxicity $(46 \%$ of cycles), followed by nausea ( $11 \%$ of cycles) and diarrhoea $(11 \%$ of cycles). In all, 14 patients (61\%) developed mild neuropathy 1-8 months after the first dose of chemotherapy.

In an attempt to reduce hospitalisation, the TPFL-4 regimen was developed in which G-CSF was started earlier and treatment was compressed into the first 4 days of the 4-week cycle (Colevas et al, 1999). In all, 30 stage III - IV SCCHN patients received two loading doses of oral leucovorin $100 \mathrm{mg}$ followed by docetaxel $\left(60 \mathrm{mg} \mathrm{m}^{-2}\right)$ $\mathrm{d} 1$ and then infusions of cisplatin $\left(31.25 \mathrm{mg} \mathrm{m}^{-2} \mathrm{day}^{-1}\right), 5$-FU $\left(700 \mathrm{mg} \mathrm{m}^{-2} \mathrm{day}^{-1}\right)$ and leucovorin $\left(500 \mathrm{mg} \mathrm{m}^{-2} \mathrm{day}^{-1}\right)$ over 4 days. G-CSF was given $\mathrm{d} 4-10$ and ciprofloxacin on $\mathrm{d} 5-15$. The ORR was 93\%, with $63 \%$ CRs and 30\% PRs. Primary tumour site clinical and pathological responses were 93 and 68\%, respectively. The originally reported 2-year overall survival and disease-free survival rates were 87 and 57\%, respectively (Colevas et al, 1999). A more recent analysis (median follow-up 30 months) reported the 2-year overall survival and disease-free survival rates as 83 and
$53 \%$, respectively (Posner et al, 2000). Haematological toxicity was generally mild, with grade III - IV neutropenia, thrombocytopenia, and anaemia reported during 8,6 and $2 \%$ of cycles, respectively (Colevas et al, 1999). Mucositis was the most prominent nonhaematological grade III - IV event ( $48 \%$ of cycles), followed by nausea/vomiting ( $15 \%$ of cycles). These values represent major reductions in haematological and infectious toxicities compared with patients in TPFL-5. As a result, hospitalization was reduced to approximately $14 \%$, the main cause of which was dehydration.

The op-TPFL trial, an outpatient study, represents a further docetaxel-TPFL regimen modification (Colevas et al, 2002). The objective of the study was to allow stage III - IV SCCHN patients to receive TPFL chemotherapy at home with intensive nursing support. Two doses of leucovorin $100 \mathrm{mg}$ were given as oral loading. This was followed by docetaxel $60-95 \mathrm{mg} \mathrm{m}^{-2} \mathrm{~d} 1$, cisplatin $100 \mathrm{mg} \mathrm{m}^{-2} \mathrm{~d} 1,5-\mathrm{FU} 700 \mathrm{mg} \mathrm{m}^{-2} \mathrm{~d} 1-4$ and leucovorin $500 \mathrm{mg} \mathrm{m}^{-2}$ day $1-4$ in a 3 -week cycle. G-CSF and antibiotics were administered, starting $6 \mathrm{~h}$ after the end of chemotherapy. The MTD of docetaxel was $90 \mathrm{mg} \mathrm{m}^{-2}$ with G-CSF support. The ORR was $94 \%$ and the CR $44 \%$ in the 34 treated patients. At a median followup of 12 months, 27 (79\%) patients were alive, with $18(53 \%)$ patients free of disease progression. Neutropenia and mucositis were the most frequently observed toxicities. Of the 15 patient who received 42 cycles administered at the MTD, grade III-IV neutropenia and mucositis were observed in $15(67 \%)$ and 5 (33\%) patients, respectively. Febrile neutropenia occurred in 
only $1(7 \%)$ patient. These results suggest that home-administered op-TPFL is a viable clinical option.

\section{Docetaxel plus PF regimens}

The TPFL regimens are intensive and associated with considerable toxicity. Patients routinely require G-CSF support and a significant proportion are hospitalised either for treatment or for treatmentrelated toxicity. In many patients age and comorbidities rule out such dose-intensive chemotherapy regimens. Intermediate doseintensive regimens involving docetaxel in combination with PF may be equally efficacious, providing alternatives in these patient groups. Three trials in which this intermediate-dose approach was investigated are discussed here and summarised in Table 3.

In the TAX 708 study, 43 chemonaïve patients with locally advanced SCCHN received docetaxel $75 \mathrm{mg} \mathrm{m}^{-2} \mathrm{~d} 1$, cisplatin $75 \mathrm{mg} \mathrm{m}^{-2}$ (level I; $N=13$ ) or $100 \mathrm{mg} \mathrm{m}^{-2}$ (level II; $N=30$ ) d1 and continuous 5-FU $1000 \mathrm{mg} \mathrm{m}^{-2}$ day $^{-1} \mathrm{~d} 1-4$ (Posner et al, 2001b). Ciprofloxacin was administered to all patients day 5-15 and G-CSF was permitted to manage febrile neutropenia or treatment-delaying myelosuppression. The ORR was $93 \%$ and the CR $40 \%$. A complete clinical response was seen in $57 \%$ of assessable tumours (Posner et al, 2001b). At a recent follow-up (median 26 months), the 2-year overall survival rate was $82 \%$ (Posner et al, 2001c). Of the grade III - IV toxicities, neutropenia affected $95 \%$ of patients; however, febrile neutropenia and infection affected only $19 \%$ and $2 \%$ of patients, respectively (Posner et al, 2001b). Other grade III-IV toxicities include stomatitis $(30 \%)$, transient renal problems $(30 \%)$, nausea $(19 \%)$ and diarrhoea (9\%) (Posner et al, 2001b).

In a similar study (TAX $017 \mathrm{HN}$ ), 48 patients with locally advanced SCCHN received docetaxel $75 \mathrm{mg} \mathrm{m}^{-2}$ and cisplatin $75 \mathrm{mg} \mathrm{m}^{-2}$ (level I) or $100 \mathrm{mg} \mathrm{m}^{-2}$ (level II) $\mathrm{d} 1$, followed by continuous infusions of 5 -FU $750 \mathrm{mg} \mathrm{m}^{-2}$ day $^{-1}$ over 5 days
(Schrijvers et al, 1999). Owing to infectious complications seen in the first 18 patients, ciprofloxacin was added from d5 to 15 . Prior to this, six patients developed infections leading to hospitalisation. Grade III-IV neutropenia was reported in 88 and $63 \%$ of patients in the level I and II groups, respectively. An ORR of $71 \%$ was observed. At a recent follow-up (median 24 months), the 2-year overall survival rate was $42 \%$ (Posner et al, 2001c).

Janinis et al (2001) administered docetaxel $80 \mathrm{mg} \mathrm{m}^{-2} \mathrm{~d} 1$, cisplatin $40 \mathrm{mg} \mathrm{m}^{-2} \mathrm{~d} 2$ and $\mathrm{d} 3$ and continuous 5-FU $1000 \mathrm{mg} \mathrm{m}^{-2}$ day $^{-1} \mathrm{~d} 1-3$ every 4 weeks in chemonaïve patients with locally advanced SCCHN. All patients received G-CSF d4-9. A maximum of four chemotherapy cycles were allowed and radiation therapy was planned after completion of chemotherapy. The ORR postchemotherapy was $90 \%$ with a CR of $20 \%$. After radiotherapy, the ORR was $95 \%$ with a CR that increased to $73 \%$. After a median follow-up of 36 months, median disease-free and overall survival had not been reached. The 2-year survival rate was $60 \%$. Grade III - IV toxicity was limited to leucopenia (25\%), febrile neutropenia (10\%), grade IV infection (10\%) and grade IV diarrhoea $(5 \%)$. The most common acute nonhaematological toxicities included alopecia, mucositis and peripheral sensory neuropathy. Alopecia was reversible, and mucositis was mild and did not require hospitalisation. Peripheral neuropathy was seen in $25 \%$ of patients, but was of mild degree with late occurrence.

\section{ONGOING PHASE III INDUCTION STUDIES INCORPORATING DOCETAXEL}

It is apparent that docetaxel, when used in conjunction with standard induction therapy (cisplatin, 5-FU with or without leucovorin), has significant activity in locally advanced SCCHN. Consistently high 2-year survival rates and ORRs have been

Table 3 Docetaxel plus PF induction regimens for locally advanced SCCHN

\begin{tabular}{|c|c|c|c|c|c|c|}
\hline Study & $\begin{array}{c}\text { Number of } \\
\text { patients } \\
\text { entered }\end{array}$ & $\begin{array}{l}\text { Patient/disease } \\
\text { characteristics }\end{array}$ & Regimen & OR $^{\mathrm{a}}(\%)$ & $C^{a}(\%)$ & $\begin{array}{l}\text { Grade III-IV toxicities } \\
\text { in } \geqslant 5 \% \text { of patients (\%) }\end{array}$ \\
\hline $\begin{array}{l}\text { TAX } 708 \\
\text { Posner et al } \\
\text { (200 Ib) } \\
\text { Phase } 1 / 11 \\
(n=43)\end{array}$ & 43 & $\begin{array}{l}\text { Locally advanced SCCHN } \\
\text { ECOG PS } 0 \text { or I } \\
\text { CT-naïve and no prior RT } \\
\text { or surgery for SCCHN }\end{array}$ & $\begin{array}{l}\text { Docetaxel } 75 \mathrm{mg} \mathrm{m}^{-2} \text { i.v. dl; Cisplatin } \\
75 \mathrm{mg} \mathrm{m}^{-2} \text { or } 100 \mathrm{mg} \mathrm{m}^{-2} \text { i.v. dl; } \\
5 \text {-FU } 1000 \mathrm{mg} \mathrm{m}^{-2} \text { day }^{-1} \mathrm{CIVI} \mathrm{dl}-4 \\
\text { Repeat q3wk for up to three cycles, } \\
\text { followed by institution-specific definitive } \\
\text { therapy }\end{array}$ & 93 & 40 & $\begin{array}{l}\text { Neutropenia (95); stomatitis (30); } \\
\text { hypomagnesaemia/hypocalcaemia } \\
\text { (30); febrile neutropenia (19); } \\
\text { nausea (19); diarrhoea (9); } \\
\text { vomiting (7); dehydration (7); } \\
\text { thrombocytopenia (5); } \\
\text { neurological-hearing (5); } \\
\text { liver enzyme abnormalities (5) }\end{array}$ \\
\hline $\begin{array}{l}\text { Janinis et al }(2001) \\
\text { Phase II } \\
(n=20)\end{array}$ & 20 & $\begin{array}{l}\text { Locally advanced SCCHN } \\
\text { WHO PS } 0-2 \\
\text { CT- and RT-naïve }\end{array}$ & $\begin{array}{l}\text { Docetaxel } 80 \mathrm{mg} \mathrm{m}^{-2} \text { i.v. dl; Cisplatin } \\
40 \mathrm{mg} \mathrm{m}^{-2} \text { i.v. D2,3; } 5-\mathrm{FU} \\
1000 \mathrm{mg} \mathrm{m}^{-2} \text { day }^{-1} \mathrm{CIVI} \mathrm{dl}-3 \\
\text { Repeat q4wk for up to four cycles, } \\
\text { followed by definitive RT }\end{array}$ & 90 & 20 & $\begin{array}{l}\text { Leucopenia (25); febrile } \\
\text { neutropenia (10); } \\
\text { Infection (10); } \\
\text { diarrhoea (5) }\end{array}$ \\
\hline $\begin{array}{l}\text { TAX 0I7HN } \\
\text { Schrijvers et al } \\
(1999) \\
\text { Phase } 1 / \| 1 \\
(n=48)\end{array}$ & $48^{b}$ & $\begin{array}{l}\text { Locally advanced SCCHN } \\
\text { ECOG PS } 0 \text { or I } \\
\text { No prior cancer treatment }\end{array}$ & $\begin{array}{l}\text { Docetaxel } 75 \mathrm{mg} \mathrm{m}^{-2} \text { i.v. dl; Cisplatin } \\
75 \mathrm{mg} \mathrm{m}^{-2} \text { (level I) or } 100 \mathrm{mg} \mathrm{m}^{-2} \\
\text { (level II) i.v. dl; 5-FU } 750 \mathrm{mg} \mathrm{m}^{-2} \text { day }^{-1} \\
\text { CIVI dI -5 } \\
\text { Repeat q3wk for up to four } \\
\text { cycles, followed by definitive RT }\end{array}$ & 71 & 0 & $\begin{array}{l}\text { Level I ( } n=\mid 7) \text { : neutropenia (76); } \\
\text { infection ( I3); stomatitis (6); } \\
\text { diarrhoea (6) } \\
\text { Level II ( } n=\mid 1 \text { ): neutropenia (63); } \\
\text { infection ( I8); stomatitis (9); } \\
\text { nausea (9); vomiting (9) }\end{array}$ \\
\hline
\end{tabular}

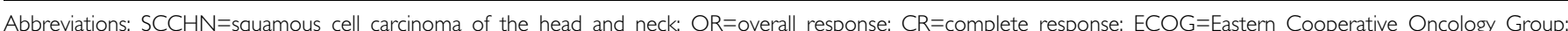
$\mathrm{PS}=$ performance status; $\mathrm{CT}=$ chemotherapy; RT=radiotherapy; i.v.=intravenously; 5-FU=5-fluorouracil; $\mathrm{CIVI}=$ continuous intravenous infusion; WHO=World Health Organization; NR=not reported.

aFor the intention-to-treat population, ' Unpublished data. 
observed across phase II studies in the range $42-82$ and $71-$ $100 \%$, respectively (Posner et al, 2001c). Each of the phase II studies discussed has used a slightly different regimen with varying concentrations of chemotherapy in 3- or 4-week cycles. The study results have suggested somewhat different response rates, overall survival rates and toxicity profiles. This may be attributed to factors such as differences in patient selection or subtle differences in schedule-related multidrug interactions.

Given the encouraging phase II experience with docetaxel induction regimens, and the need to further investigate the various regimens in a randomised, controlled setting, phase III studies of two TPF-based regimens $v s$ PF are warranted and are under way (Posner et al, 2000). A phase III trial (TAX 324) is being conducted mainly in the USA, with some centres in Europe and South America. This trial is evaluating three cycles of TPF (docetaxel $75 \mathrm{mg} \mathrm{m}^{-2} \mathrm{~d} 1$, cisplatin $100 \mathrm{mg} \mathrm{m}^{-2} \mathrm{~d} 1$ and 5 -FU $1000 \mathrm{mg} \mathrm{m}^{-2}$ $\mathrm{d} 1-4$ every 3 weeks) $v s$ three cycles of PF (cisplatin $100 \mathrm{mg} \mathrm{m}^{-2} \mathrm{~d} 1$ and 5-FU $1000 \mathrm{mg} \mathrm{m}^{-2} \mathrm{~d} 1-5$ every 3 weeks). This trial comprises a sequential therapy design incorporating postinduction chemoradiotherapy. Patients in both arms are treated with definitive chemoradiation, with weekly carboplatin for a maximum of seven doses following induction chemotherapy. A second study conducted by the EORTC (TAX 323) is evaluating four cycles of TPF (docetaxel $75 \mathrm{mg} \mathrm{m}^{-2} \mathrm{~d} 1$, cisplatin $75 \mathrm{mg} \mathrm{m}^{-2} \mathrm{dl}$ and $5-\mathrm{FU}$ $750 \mathrm{mg} \mathrm{m}^{-2} \mathrm{~d} 1-5$ every 3 weeks) vs four cycles of PF (cisplatin $100 \mathrm{mg} \mathrm{m}^{-2} \mathrm{~d} 1$ and 5 -FU $1000 \mathrm{mg} \mathrm{m}^{-2} \mathrm{~d} 1-5$ every 3 weeks). A 7week course of radiotherapy is to commence within 4-7 weeks of completing the last chemotherapy cycle. These ongoing, large-scale, randomised trials are expected to confirm the positive benefits of adding docetaxel to PF-based regimens, as already demonstrated in the phase II setting.

\section{DOCETAXEL-BASED CHEMORADIATION REGIMENS FOR LOCALLY ADVANCED DISEASE}

In recent controlled studies, PF-based chemoradiation regimens, used as induction or definitive therapy, have demonstrated improved efficacy compared with conventional or hyperfractionated radiotherapy alone in locally advanced SCCHN (Vokes et al, 1995; Brizel et al, 1998). The activity of docetaxel in SCCHN, coupled with the drug's in vitro radiosensitizing properties (Creane et al, 1999; Mason et al, 1999; Pradier et al, 2001), provide the basis for clinical trials with docetaxel as a component of concurrent or alternating chemoradiation in locally advanced SCCHN (Koukourakis et al, 1999; Hesse et al, 2000; Tishler et al, 2002).

Docetaxel-based chemoradiation regimens have been shown to be feasible and active as induction and adjuvant therapy. The phase I/II study by Tishler et al (2002) considered daily radiation concurrent with weekly docetaxel in 21 patients with stage III - IV
SCCHN, who responded poorly to induction chemotherapy, and demonstrated an ORR of $86 \%$ (CR 57\%). Radiation was delivered at $2 \mathrm{Gyday}^{-1}$, to a total dose of $66-74 \mathrm{~Gy}$. The MTD of weekly docetaxel in this regimen was $25 \mathrm{mg} \mathrm{m}^{-2}$. Mucositis was the major acute toxicity, occurring at grade III in all patients receiving docetaxel $25 \mathrm{mg} \mathrm{m}^{-2}$. Swallowing problems represented the main long-term toxicity, although no patient remained feeding-tube dependent. Three-year survival was $>60 \%$ in this poor prognosis group of patients.

Chemoradiation therapies with docetaxel-cisplatin have achieved an ORR as high as $100 \%$ (Varveris et al, 1999; Budach et $a l, 2000)$. The chemoradiation protocol considered by Budach et al (2000) was devised to reduce oral toxicity. A total of 15 patients with inoperable, recurrent head and neck cancer received three cycles of docetaxel $\left(50-60 \mathrm{mg} \mathrm{m}^{-2} \mathrm{~d} 1\right)$ and cisplatin $\left(15 \mathrm{mg} \mathrm{m}^{-2} \mathrm{~d} 2-5\right)$ during weeks 1,4 and 7 alternating with two courses of radiotherapy $(5 \times 2 \mathrm{~Gy}$; total dose $40 \mathrm{~Gy})$ in weeks $2-3$ and $5-6$. The recommended dose of docetaxel was $50 \mathrm{mg} \mathrm{m}^{-2}$, as $60 \mathrm{mg} \mathrm{m}^{-2}$ led to unacceptable systemic toxicity in the first 12 patients treated. An ORR of $92 \%$ was achieved, with acceptable levels of oral toxicity.

Varveris et al (1999) demonstrated that the radiosensitizing effect of docetaxel-cisplatin on hyperfractionated radiotherapy enables an ORR of $100 \%$ (CR 59\%). Docetaxel and cisplatin were both given at $30 \mathrm{mg} \mathrm{m}^{-2}$ twice weekly to 54 patients. This dose was reduced to $15-20 \mathrm{mg} \mathrm{m}^{-2}$ because of severe acute toxicity in the first 10 patients. Major toxicities included grade III - IV mucositis (86\%), grade I - III hypersensitivity reactions $(11 \%)$ and grade III myelotoxicity (11\%).

Further studies are needed to elucidate the relative efficacy and toxicity of these concurrent radiation regimens $v s$ the traditional sequential approach of induction chemotherapy followed by definitive radiotherapy.

\section{CONCLUSIONS}

Unmet needs in SCCHN care have stimulated intensive investigation into new agents with potential in induction chemotherapy and chemoradiotherapy regimens. Docetaxel has emerged as one of the most active agents in SCCHN, and is particularly efficacious as a component of induction therapy in locally advanced disease. The results of phase II studies investigating TPF induction regimens demonstrate consistently high 2-year survival rates and ORRs across all trials, in the range of $42-82$ and $71-100 \%$, respectively (Posner et al, 2001c). An acceptable toxicity profile is seen with TPF-based regimens, with neutropenia and gastrointestinal complaints accounting for the majority of adverse events. The encouraging phase II results are being validated in the ongoing, large-scale, randomised phase III studies comparing TPF with PF regimens.

\section{REFERENCES}

Braakhuis BJ, Kegel A, Welters MJ (1994) The growth inhibiting effect of docetaxel (Taxotere) in head and neck squamous cell carcinoma xenografts. Cancer Lett 81: 151 - 154

Brizel DM, Albers ME, Fisher SR, Scher RL, Richtsmeier WJ, Hars V, George SL, Huang AT, Prosnitz LR (1998) Hyperfractionated irradiation with or without concurrent chemotherapy for locally advanced head and neck cancer. N Engl J Med 338: 1798 - 1804

Budach W, Hehr T, Belka C, Bamberg M (2000) Alternating chemoradiation with docetaxel (D)/cisplatin (C) and involved field radiotherapy for recurrent, inoperable, and previously irradiated head and neck cancer (HNC). Proc Am Soc Clin Oncol 19: 1649

Caponigro F, Massa E, Manzione L, Rosati G, Biglietto M, De Lucia L, Sguotti C, Sganga P, Avallone A, Comella P, Mantovani G, Comella G (2001) Docetaxel and cisplatin in locally advanced or metastatic squamous-cell carcinoma of the head and neck: a phase II study of the Southern Italy Cooperative Oncology Group (SICOG). Ann Oncol 12: $199-202$

Catimel G, Verweij J, Mattijssen V, Hanauske A, Piccart M, Wanders J, Franklin H, Le Bail N, Clavel M, Kaye SB (1994) Docetaxel (Taxotere): an active drug for the treatment of patients with advanced squamous cell carcinoma of the head and neck. EORTC Early Clinical Trials Group. Ann Oncol 5: $533-537$ 
Clark JR, Busse PM, Norris CM, Andersen JW, Dreyfuss AI, Rossi RM, Poulin MD, Colevas AD, Tishler RB, Costello R, Lucarini JW, Lucarini D, Thornhill L, Lackey M, Peters E, Posner MR (1997) Induction chemotherapy with cisplatin, fluorouracil, and high-dose leucovorin for squamous cell carcinoma of the head and neck: long-term results. Clin Oncol 15: 3100 - 3110

Colevas AD, Adak S, Amrein PC, Barton JJ, Costello R, Posner MR (2000) A phase II trial of palliative docetaxel plus 5-fluorouracil for squamous-cell cancer of the head and neck. Ann Oncol 11: 535-539

Colevas AD, Busse PM, Norris CM, Fried M, Tishler RB, Poulin M, Fabian RL, Fitzgerald TJ, Dreyfuss A, Peters ES, Adak S, Costello R, Barton JJ, Posner MR (1998) Induction chemotherapy with docetaxel, cisplatin, fluorouracil, and leucovorin for squamous cell carcinoma of the head and neck: a phase I/II trial. J Clin Oncol 16: 1331 - 1339

Colevas AD, Norris CM, Tishler RB, Fried MP, Gomolin HI, Amrein P, Nixon A, Lamb C, Costello R, Barton J, Read R, Adak S, Posner MR (1999) Phase II trial of docetaxel, cisplatin, fluorouracil, and leucovorin as induction for squamous cell carcinoma of the head and neck. J Clin Oncol 17: $3503-3511$

Colevas AD, Norris CM, Tishler RB, Lamb CC, Fried MP, Goguen LA, Gopal HV, Costello R, Read R, Adak A, Posner MR (2002) Phase I/II trial of outpatient docetaxel, cisplatin, 5-fluorouracil, leucovorin (opTPFL) as induction for squamous cell carcinoma of the head and neck (SCCHN). Am J Clin Oncol 25: 153 - 159

Colevas AD, Posner MR (2001) Docetaxel in head and neck cancer. J Clin Oncol 21: $482-486$

Couteau C, Chouaki N, Leyvraz S, Oulid-Aissa D, Lebecq A, Domenge C, Groult V, Bordessoule S, Janot F, De Forni M, Armand JP (1999) A phase II study of docetaxel in patients with metastatic squamous cell carcinoma of the head and neck. Br J Cancer 81: 457 - 462

Creane M, Seymour CB, Colucci S, Mothersill C (1999) Radiobiological effects of docetaxel (Taxotere): a potential radiation sensitizer. Int $J$ Radiat Biol 75: 731 - 737

Domenge C, Hill C, Lefebvre JL, De Raucourt D, Rhein B, Wibault P, Marandas P, Coche-Dequeant B, Stromboni-Luboinski M, SanchoGarnier H, Luboinski B (2000) Randomized trial of neoadjuvant chemotherapy in oropharyngeal carcinoma. French Groupe d'Etude des Tumeurs de la Tête et du Cou (GETTEC). Br J Cancer 83: 1594- 1598

Dreyfuss AI, Clark JR, Norris CM, Rossi RM, Lucarini JW, Busse PM, Poulin MD, Thornhill L, Costello R, Posner MR (1996) Docetaxel: an active drug for squamous cell carcinoma of the head and neck. J Clin Oncol 14: $1672-1678$

Forastiere AA (2000) Head and neck cancer: overview of recent developments and future directions. Semin Oncol 27: 1-4

Glisson BS, Murphy BA, Frenette G, Khuri FR, Forastiere AA (2002) Phase II trial of docetaxel and cisplatin combination chemotherapy in patients with squamous cell carcinoma of the head and neck. J Clin Oncol 20: $1593-1599$

Hesse K, Heinrich B, Zimmermann F, Kau R, Sommer G, Achterrath W, Molls M, Feldmann HJ (2000) Combined radiochemotherapy with docetaxel in patients with unresectable locally advanced head and neck tumors. Strahlenther Onkol 176: 67-72

Janinis J, Papadakou M, Panagos G, Panousaki A, Georgoulias V, Hatzidaki D, Lefantzis D, Dokianakis G (2001) Sequential chemoradiotherapy with docetaxel, cisplatin, and 5-fluorouracil in patients with locally advanced head and neck cancer. Am J Clin Oncol 24: 227-231

Johnson N (2001) Tobacco use and oral cancer: a global perspective. J Dent Educ 65: 328 - 339

Kienzer HR, Schweiger J, Baur M, DeSantis M, Pöhnl R, Gerber E, Soucek B, Schernhammer E, Postner G, Kraus R, Pont J, Schlappack O, SchratterSehn AU, Wicke W, Dittrich C (1998) Docetaxel (d)/cisplatin (p) as firstline therapy in head and neck cancer (HNC). Proc Am Soc Clin Oncol 17: 1566

Koukourakis MI, Bizakis JG, Skoulakis CE, Kyrmizakis D, Giatromanolaki A, Papadakis CE, Prokopakis E, Amanakis Z, Hellidonis ES (1999) Combined irinotecan, docetaxel and conventionally fractionated radiotherapy in locally advanced head and neck cancer. A phase I dose escalation study. Anticancer Res 19: $2305-2309$

Lavelle F, Bissery MC, Combeau C, Riou JF, Vrignaud P, Andre S (1995) Preclinical evaluation of docetaxel (Taxotere). Semin Oncol 22: 3-16

Lefebvre JL, Chevalier D, Luboinski B, Kirkpatrick A, Collette L, Sahmoud $\mathrm{T}$ (1996) Larynx preservation in pyriform sinus cancer: preliminary results of a European Organization for Research and Treatment of Cancer phase III trial. EORTC Head and Neck Cancer Cooperative Group. J Natl Cancer Inst 88: 890 - 899
Mason KA, Kishi K, Hunter N, Buchmiller L, Akimoto T, Komaki R, Milas L (1999) Effect of docetaxel on the therapeutic ratio of fractionated radiotherapy in vivo. Clin Cancer Res 5: $4191-4198$

Mel JR, Rodríguez R, Constenla M, Davila A, Fernández-Piera M (2000) Multicentre phase II study of docetaxel (D) and cisplatin (C) as induction chemotherapy in locally advanced squamous cell carcinoma of the head and neck (SCCHN). Ann Oncol 11: 92

Paccagnella A, Orlando A, Marchiori C, Zorat PL, Cavaniglia G, Sileni VC, Jirillo A, Tomio L, Fila G, Fede A (1994) Phase III trial of initial chemotherapy in stage III or IV head and neck cancers: a study by the Gruppo di Studio sui Tumori della Testa e del Collo. J Natl Cancer Inst 86: $265-272$

Parker SL (1996) Cancer Statistics. CA Cancer J Clin 65: 5-27

Parkin DM, Muir CS (1992) Cancer incidence in five continents. Comparability and quality of data. IARC Sci Publ 120: 45 - 173

Pignon JP, Bourhis J, Domenge C, Designe L (2000) Chemotherapy added to locoregional treatment for head and neck squamous-cell carcinoma: three meta-analyses of updated individual data. MACH-NC Collaborative Group. Meta-Analysis of Chemotherapy on Head and Neck Cancer. Lancet 355: 949 - 955

Posner MR (2001a) Docetaxel in squamous cell cancer of the head and neck. Anticancer Drugs 12(Suppl 1): S21 - S24

Posner MR, Colevas AD, Tishler RB (2000) The role of induction chemotherapy in the curative treatment of squamous cell cancer of the head and neck. Semin Oncol 27: $13-24$

Posner MR, Glisson B, Frenette G, Al Sarraf M, Colevas AD, Norris CM, Seroskie JD, Shin DM, Olivares R, Garay CA (2001b) Multicenter phase I - II trial of docetaxel, cisplatin, and fluorouracil induction chemotherapy for patients with locally advanced squamous cell cancer of the head and neck. J Clin Oncol 19: 1096 - 1104

Posner MR, Vermoken JB, Janinis J, Bragas B, Yver A (2001c) Survival analysis of induction therapy with Docetaxel (Taxotere) $(\mathrm{T})$ containing regimens in patients with locally advanced squamous cell carcinoma of the head and neck (SCCHN). Proc Am Soc Clin Oncol 20: 2564

Pradier O, Rave-Frank M, Lehmann J, Lucke E, Boghun O, Hess CF, Schmidberger H (2001) Effects of docetaxel in combination with radiation on human head and neck cancer cells (ZMK-1) and cervical squamous cell carcinoma cells (CaSki ). Int J Cancer 91: 840 - 845

Schantz SP, Harrison LB, Forastiere AA (2001) Tumors of the nasal cavity and paranasal sinuses, nasopharnyx, oral cavity, and oropharnyx. In Cancer: Principles and Practice of Oncology, Devita VTJ, Hellman S, Rosenberg SA (eds) pp 797-860. Philadelphia: Lippincott Williams \& Wilkins.

Schneider M, Etienne MC, Milano G, Thyss A, Otto J, Dassonville O, Mobayen H, Saudes L, Guillot T, Demard F (1995) Phase II trial of cisplatin, fluorouracil, and pure folinic acid for locally advanced head and neck cancer: a pharmacokinetic and clinical survey. J Clin Oncol 13: $1656-1662$

Schoffski P, Catimel G, Planting AS, Droz JP, Verweij J, Schrijvers D, Gras L, Schrijvers A, Wanders J, Hanauske AR (1999) Docetaxel and cisplatin: an active regimen in patients with locally advanced, recurrent or metastatic squamous cell carcinoma of the head and neck. Results of a phase II study of the EORTC Early Clinical Studies Group. Ann Oncol 10: $119-122$

Schoffski P, Weihkopf T, Ganser A (1998) Advanced head and neck cancer and clinical experience of an effective new agent: docetaxel. Anticancer Res 18: $4751-4756$

Schrijvers D, Johnson J, Jiminez U, Gore M, Kosmidis P, Szpirglas H, Robbins K, Oliveira J, Lewensohn R, Schuller J, Riviere A, Arvay C, Langecker P, Jacob H, Cvitkovic E, Vokes E (1998) Phase III trial of modulation of cisplatin/fluorouracil chemotherapy by interferon alfa-2b in patients with recurrent or metastatic head and neck cancer. Head and Neck Interferon Cooperative Study Group. J Clin Oncol 16: $1054-1059$

Schrijvers D, Van Herpen C, Kerger J, Joosens E, Le Bouder C, Castelijns J, Vermorken J (1999) Phase I - II study with docetaxel (D), cisplatin (C) and 5-fluorouracil (5-FU) in patients (PTS) with locally advanced inoperable squamous cell carcinoma of the head and neck (SCCHN). Proc Am Soc Clin Oncol 18: 1524

Schrijvers D, Vermorken JB (2000) Role of taxoids in head and neck cancer Oncologist 5: 199 - 208

Sommer K, Peters SO, Robins IH, Raap M, Wiedemann GJ, Remmert S, Sieg P, Bittner C, Feyerabend T (2001) A preclinical model for experimental chemotherapy of human head and neck cancer. Int J Oncol 18: $1145-1149$ 
Specht L, Larsen SK, Hansen HS (2000) Phase II study of docetaxel and cisplatin in patients with recurrent or disseminated squamous-cell carcinoma of the head and neck. Ann Oncol 11: $845-849$

Tishler R, Colevas AD, Norris CM, Lamb C, Nixon A, Lake-Willcutt B, Costello R, Case MA, Adak S, Busse PM, Posner MR (2002) A phase I/II trial of concurrent docetaxel and once daily radiation after induction chemotherapy in patients with poor prognosis squamous cell cancer of the head and neck. Cancer 95: $1427-1481$

Tubiana-Mathieu N, Genet D, Cupissol D (2000) Final results of phase II study of patients (pts) with metastatic or recurrent squamous cell carcinoma of the head and neck (SCCHN) treated with docetaxel (D) and 5-fluorouracil (5-FU). Proc Am Soc Clin Oncol 19: 1656

Varveris HC, Mazonakis M, Prassopoulos P, Damilakis J, Papadakis H, Skoulakis H, Velegrakis G, Hatzimanolis P, Manios A, Haldeopoulos D,
Mavroudis D, Geogroulias V, Kouroussis C, Vlachonikolis J, Gourtsogiannis N (1999) Concurrent hyperfractionated (b.i.d.) irradiation and docetaxel + cisplatinum chemotherapy for stage II-IV squamous cell carcinoma of the head and neck. Proc Am Soc Clin Oncol 18: 1707

Vokes EE, Kies M, Haraf DJ, Mick R, Moran WJ, Kozloff M, Mittal B, Pelzer H, Wenig B, Panje W (1995) Induction chemotherapy followed by concomitant chemoradiotherapy for advanced head and neck cancer: impact on the natural history of the disease. J Clin Oncol 13: $876-883$

Vokes EE, Schilsky RL, Weichselbaum RR, Kozloff MK, Panje WR (1990) Induction chemotherapy with cisplatin, fluorouracil, and high-dose leucovorin for locally advanced head and neck cancer: a clinical and pharmacologic study. J Clin Oncol 8: $241-247$ 